\title{
LANDASAN METODOLOGIS TEOLOGI PENDIDIKAN ISLAM
}

\section{Undang Burhanudin}

UIN Sunan Gunung Djati Bandung Jl. A.H. Nasution No. 105 Cibiru - Bandung 40614

Email: undangburhanudin@yahoo.com

\begin{abstract}
ABSTRAK
Tulisan ini bertujuan menggambarkan bahwa dalam menginterpresaikan ayat-ayat alQur'an yang berhubungan dengan pendidikan memiliki sejumlah konvensi/kaidah yang harus dipegang oleh peneliti pendidikan Islam. Konvensi/kaidah tersebut bisa bersifat metodologis dan teologis. Secara metodologis, upaya untuk menafsirkan ayat-ayat pendidikan yang terdapat dalam al-Qur'an berasal dari metode tafsir alQur'an. Secara umum, metode tafsir al-Qur'an tidak jauh berbeda dengan metode untuk menafsirkan teks/naskah pada umumnya. Hal yang paling membedakan adalah justru pada naskah itu sendiri yang berbentuk kitab suci. Oleh karena itu perlu ada pemahaman teologis tertentu ketika memperlakukan naskah kitab suci al Qur'an sebagai objek kajian/tafsir/penelitian. Al-Qur'an adalah firman Allah SWT yang berisi petunjuk bagi sekalian manusia. Sebagai firman Allah SWT, hanya Allah semata yang maha mengetahui semua maksud yang terkandung dalam setiap ayat alQur'an. Tetapi sebagai petunjuk, firman itu harus dipahami agar dapat diamalkan. Atas dasar itu, upaya untuk memahami al-Qur'an harus terus dilakukan, tidak terkecuali untuk memahami ayat-ayat al-Qur'an yang berkaitan dengan pendidikan. Ragam upaya tersebut, yang meliputi prinsip dasar, metode analisis dan metode penelitian terangkum dalam satu konsep yaitu landasan metodologis teologi pendidikan Islam.
\end{abstract}

Kata kunci: Metodologi, Teologis, Pendidikan Islam

\begin{abstract}
This paper aims to describe that there is a number of conventions/rules that must be considered by the researcher of Islamic education in interpreting the verses of the Qur'an related to education. The conventions/rules can be in the form of methodological and theological. Methodologically, an attempt to interpret the verses of education contained in the Qur'an comes from the Qur'an interpretation methods. In general, the method of interpretation of the Qur'an is not different from the method of interpreting the text/script in general. The most distinguishing thing is the text itself in the form of the holy book. Therefore, there needs to be a certain theological understanding to treat the holy Quran as an object of study/interpretation/research. The Qur'an is the word of Allah SWT that contains instructions for all humans. As the word of Allah, only God knows all intents contained in each verse of the Qur'an. But as a guide, the word must be understood in order to be carried out. On that basis, efforts to understand the Qur'an should be done, includingto understand the verses of the Qur'an related to education. V ariety of these efforts including the basic principles, methods of analysis and research methods are summarized in the concept of theology methodological foundation of Islamic education.
\end{abstract}

Keywords: Methodology, Theological, Islamic Education. 


\section{PENDAHULUAN}

Al-Qur'an berfungsi sebagai hudan/petunjuk. Salah satu indikasinya, alQur'an begitu peduli pada ajaran tentang pembentukan moral yang baik. Prinsipprinsip keadilan (QS. Al-Maidah, [5]: 95), musyawarah (QS. Al-Syura, [42]: 38), dan perdamaian (QS. Al-A'raf, [7]: 56) merupakan prinsip dasar agar manusia memiliki moral yang baik. Agar prinsip dasar moral tersebut dapat dipahami maka manusia memerlukan perangkat metodis dan sistematis untuk mengungkap isi dan makna ayat-ayat al-Qur'an sehingga mudah diaplikasikan oleh manusia. Dengan demikian, metode penyelidikan terhadap ayat-ayat al-Qur'an menjadi hal yang sangat penting diperhatikan oleh manusia terutama oleh umat Islam sebagai kitab sucinya di samping sistematikanya.

Sebagian pemerhati/pengkaji dan pembaca al-Qur'an memandang bahwa sistematika sajian al-Qur'an itu tidak sistematis bahkan dianggap kacau. Mereka sering menemukan suatu uraian yang tidak selesai namun tiba-tiba sudah melompat ke uraian lain dan tidak berhubungan dengan uraian sebelumnya (Quraish Shihab, 1998: 239). Pandangan tentang sistematika al-Qur'an semacam itu dipatahkan oleh pandangan lain. Mereka menganggap bahwa pendapat pertama itu terlampau linier, kaku dan konvensional dalam memandang sistematika al-Qur'an. Al-Qur'an tidak disusun berdasarkan tema atau bahasan tertentu, juga tidak disusun berdasarkan kronologis diturunkannya. Al-Qur'an hanya disusun berdasarkan tertib mushaf yang diyakini oleh para penyusunnya sebagai satu kesatuan terpadu dan tidak dapat dipisah-pisahkan. Oleh karenanya al-Qur'an harus dipahami secara terpadu/holistik/komprehensif serta tidak disarankan dipahami secara parsial/terpisah-pisah dan terpotong-potong.

Karena umat Islam lebih banyak yang terlalu terobsesi dengan sistematika al-Qur'an yang konvensional dan linier akibatnya ada kebekuan dalam memahami isi dan sistematika al-Qur'an. Fazlur Rahman mengatakan, ada dua persoalan yang dihadapi kaum Muslimin dalam menganalisis perkembangan ideide al-Qur'an, yaitu: pertama, mereka kurang menghayati relevansi untuk masa sekarang. Karena itu, mereka tidak dapat menyajikan al-Qur'an untuk memenuhi kebutuhan-kebutuhan umat manusia masa kini. Kedua, mereka kawatir jika penyajian al-Qur'an akan menyimpang dari pendapat-pendapat yang telah diterima secara tradisional (Fazlur Rahman, 1983: 11). Pendapat tradisional umumnya berasal dari pemahaman bahwa al-Qur'an harus sistematis, linier dan runtut.

Ide-ide tentang sistematika dan metode penelaahan al-Qur'an telah mengalami banyak perkembangan. Beberapa filosof Muslim telah menawarkan cara-cara baru dalam memahami al-Qur'an. Arkoun misalnya, menawarkan pengkajian al-Qur'an berdasarkan bacaan yang sesuai dengan suatu wacana yang didengar bukan dibaca (wacana qurani) dan bukan teks pada fase awal yang diperbincangkan oleh Nabi SAW. Menurutnya, teks tersebut adalah corvus resmi yang sifatnya tertutup (Arkoun, 1996: 45). Izutsu menawarkan kajian semantik dengan tujuan memunculkan tipe ontologi hidup yang dinamik dari al-Qur'an 
dengan penelaahan analitis dan metodologis terhadap beberapa konsep pokok al-Qur'an, yaitu konsep yang berperan dalam menentukan pembentukan visi qurani terhadap alam semesta (Izutsu, 1997: 3). Al-Farmawi memperkenalkan metode mawdlu'iy. Ia juga menawarkan pengkajian agar difokuskan terhadap alQur'an dalam konteks ide-idenya (bukan teksnya), agar ayat-ayat al-Qur'an tidak dipandang sebagai sesuatu yang parsial. Kuntowijoyo menggagas penelaahan alQur'an dengan pendekatan sintetik-analitik dan historis. Pendekatan ini melahirkan pandangan bahwa kandungan al-Qur'an itu pada dasarnya terbagi kepada dua bagian. Bagian pertama berisi tentang konsep-konsep yang cenderung abstrak dan bagian kedua berisi kisah-kisah sejarah dan amtsâl yang sifatnya konkret. Al-Souwi menggagas perlunya saintifikasi terhadap al-Qur'an (al-Souwi, 1995: 17). Artinya, al-Qur'an dapat diteliti secara ilmiah dan karenanya al-Qur,an itu menjadi ilmiah. Pandangan terakhir ini menuai perdebatan. Lebih banyak umat Islam berpendapat bahwa biarkan saja al-Qur'an berbicara sendiri dan mengungkap sendiri fenomena yang terjadi di alam semesta. Lepaskan alQur'an dari saintifikasi dan teori-teori ilmiah yang dibuat oleh manusia dan terlalu memberi peluang untuk berubah-ubah. Terlalu naif ketika al-Qur'an ditugasi untuk melegalisasi teori ilmiah atau sebaliknya terlalu dzanni kalau teoriteori ilmiah dijadikan sandaran interpretasi terhadap al-Qur'an.

Al-Qur'an berisi berbagai materi yang bersifat informatif dan ide serta argumentasinya, antara aspek dari satu subjek dengan subjek lainnya saling berhubungan. Karakteristik ini mengandaikan bahwa perlunya menggabungkan berbagai persoalan dalam satu surat agar setiap pembaca surat dapat memperoleh banyak petunjuk dalam waktu yang singkat tanpa harus membaca seluruh ayat-ayat al-Qur'an (Shihab, 1998: 244). Berdasarkan pernyataan tersebut, al-Qur'an memperlihatkan sosok totalitas kepada manusia, baik secara internal maupun eksternal. Secara eksternal al-Qur'an bukan risalah akademis namun berdasarkan sejarah penyusunan mushafnya ia dapat dikatakan akademis. Secara internal al-Qur'an mendorong seseorang untuk melakukan aksi. AlQur'an tidak menginginkan manusia sebagai penonton pasif dalam kehidupan, tetapi harus berperan aktif dengan membangun komitmen moral yang benar serta senantaiasa berambisi mencapai jalan yang lurus (Irving, 1984: 24).

Agar telaah terhadap al-Qur'an berlangsung secara total/utuh maka diperlukan suatu metodologi penelitian terhadap ayat-ayat yang terkandung dalam al-Qur'an. Ayat-ayat yang terkadung dalam al-Qur'an dapat dikelompokan ke dalam tema-tema tertentu, misalnya kesehatan, hukum, negara, politik, ibadah, sosial dan pendidikan. Ayat-ayat yang bertemakan pendidikan termasuk ayat-ayat yang saat ini banyak dibahas dan diteliti. Hal ini disebabkan oleh keadaan bahwa dunia pendidikan dewasa ini, khususnya di Indonesia sedang mengalami banyak cobaan, seperti kasus tawuran antar pelajar dan rendahnya kualitas pendidikan. Kasus-kasus tersebut memerlukan penanganan yang secara normatif memerlukan sumber-sumber alternatif di luar teori dan filsafat yang ada. Dalam konteks al-Qur'an, pendidikan merupakan bidang yang berkaitan langsung 
dengan upaya memanusiakan manusia sesuai dengan harkat dan martabatnya yang mulia di mata Tuhan. Ayat-ayat pendidikan dapat dipilah ke dalam dua kategori, yaitu 1) ayat-ayat yang memang secara tekstual bermakna pendidikan; 2) ayat-ayat yang secara tekstual tidak bermakna pendidikan namun secara kontekstual dan esensial mengandung tujuan-tujuan pendidikan.

\section{PEMBAHASAN}

Penelitian terhadap ayat-ayat al-Qur'an yang disinyalir mengandung pesanpesan pendidikan (Islam) merupakan upaya peneliti/mufassir untuk mengungkap al-Qur'an melalui penjelasan para mufassir, kemudian dicari relevansinya secara kritis dengan teori dan/atau fakta yang berlaku/terjadi pada dunia pendidikan. Dalam rangka memvalidasi proses pencarian kritis tersebut secara metodologi seorang peneliti harus menguasai berbagai macam metode tafsir seperti metode analisis semantik, tematik, hermeneutik, atau sintesa dari ketiganya.

\section{Prinsip Dasar}

Sebelum memahami berbagai metode tafsir, sebaiknya peneliti menguasai terlebih dahulu prinsip-prinsip dasar metodologi penelitian al-Qur'an. Prinsip dasar tersebut dapat dijadikan sebagai landasan baik secara teologis/moral dan metodologis/metode ketika peneliti pendidikan Islam berupaya memahami alQur'an dalam konteks pendidikan. Prinsip-prinsip dasar tersebut yaitu:

1. Al-Qur'an adalah kitab yang universal dan integral. Sifat universalitas al-Qur'an menunjukkan bahwa al-Qur'an disajikan secara garis besar/umum, sehingga berpeluang ditafsirkan dari berbagai sudut pandang dan kaya makna. Sifat integral al-Qur'an menuntut sang penafsir memiliki wawasan yang luas dan mampu memilah antara halhal yang bersifat aksidensial dengan hal yang esensial. Ada totalitas potensi akliah yang harus dimaksimalkan oleh orang yang mencoba meneliti/menafsirkan al-Qur'an secara baik (al-Kholidi, 1997: 109).

2. Semua petunjuk yang tersirat maupun tersurat di dalam al-Qur'an diberikan atas dasar pemahaman, pemikiran dan alasan tertentu yang sifat mendasar (Irving, 1984: 25).

3. Ajaran al-Qur'an muncul sebagai suatu dokumen, yang dari awal hingga akhir selalu memberikan tekanan-tekanan pada moral yang diperlukan bagi manusia yang berakal dan kreatif. Pada dasarnya, tujuan utama al-Qur'an adalah perbaikan dan mendorong kemajuan bagi manusia.

4. Isi pokok al-Qur'an itu berupa petunjuk dan pedoman hidup manusia yang intinya adalah aqidah, akhlak, dan syari'ah.

Dari empat prinsip dasar metodologi penelitian al-Qur'an tersebut dapat diuraikan beberapa metode analisis dalam penelitian al-Qur'an, diantaranya; 1) metode analisis semantik; 2) metode analisis tematik; 3), metode analisis hermeneutik. Pembagian ini tidak bersifat hirarkis, tetapi saling melengkapi. 
Metode analisis pertama dapat menjadi pelengkap bagi metode analisis kedua. Metode analisis kedua dapat mempermudah metode analisis ketiga.

\section{a. Metode analisis semantik}

Metode semantik merupakan metode yang akar teoretisnya adalah pencarian makna. Makna dapat ditemukan melalui studi hubungan antara suatu pembeda linguistik dengan simbol atau proses mental dalam aktivitas berkomunikasi. Semantik itu sendiri merupakan subdisiplin linguistik yang berupaya mengungkap makna dari berbagai bentuk simbol yang terdapat dalam suatu ungkapan yang di dalamnya terdapat medan makna untuk diinterpretasikan (Rosadisastra, 2007: 122). Medan makna adalah seperangkat unsur leksikal yang saling berhubungan. Hubungan mencerminkan budaya dari masyarakat pemakai bahasa yang bersangkutan.

Fakhrurazi mengatakan bahwa kata yang berada dalam satu medan makna dapat dikategorikan pada dua kelompok, yaitu: 1) kelompok kolokasi, yakni makna yang berada pada tempat atau dalam lingkungan yang sama. Misalnya, munculnya kata al-Qur'an, akan diikuti dengan kata-kata lain seperti rasul, tanzil, Jibril, wahyu, dan budan; 2) kelompok set, yaitu kelompok kata yang merujuk pada hubungan paradigmatik. Maksudnya, kata atau unsur hadir dalam satu paket dan satu sama lain dapat saling menggantikan. Misalnya, kata al-murâhaqah (remaja), merupakan tahap pertumbuhan yang berada di antara masa kanakkanak (Thufülab) dan dewasa. Berarti, medan makna kata 'remaja' adalah kata 'kanak-kanak' dan 'dewasa' (Rosadisastra, 2007: 123-124).

Dari segi sistematika bahasa, kajian semantik memiliki dua taraf, yakni taraf semantik leksikal dan gramatikal. Secara leksikologis, taraf semantik leksikal mencakup lima macam makna, yaitu; 1) Makna referensional dan nonreferensional. Makna referensional maksudnya, bahwa setiap kata memiliki jabatan tertentu sesuai dengan yang diacunya. Misal, dalam kata 'al-Qur'an', makna yang dapat dituju adalah sebuah kitab yang bertuliskan al-Qur'an. Makna non-referensional adalah makna yang tidak memiliki acuannya. Misalnya kata "akan", "selalu", dan "karena"; 2) Makna denotasi dan konotasi. Makna denotasi adalah makna biasa, yakni objektif dan belum bercampur dengan perasaan/emosi tertentu. Makna konotasi lebih subjektif karena sudah ada penambahan rasa atau nilai tertentu. Misal, makna konotatif kata 'hujan' adalah rahmat bagi petani yang sedang menunggu turunnya hujan, akan tetapi dapat menjadi hambatan bagi para penjual es. 3) Analisis eksistensional dan analisis intensional. Misalnya, kata 'Islam' secara intensional/terarah pada makna agama yang dianut oleh Nabi Muhammad SAW. Makna eksistensionalnya merujuk kepada beberapa makna leksikal yaitu; berserah diri, tunduk, taat, patuh, selamat, damai, sejahtera, dan integral; 4) Analisis komponensional, yaitu hubungan makna dengan kata lainnya. Misalnya, kata al-umm 'ibu' dalam al-Qur'an memiliki hubungan dengan kata al-ummah dan imâm (QS. Al-Furqan, [25]: 74). Dari konsep doa pada ayat di atas, kata al-umm berelasi dengan lahirnya imâm lil muttaqîn yang berujung lahirnya 
khairu ummah. Hal tersebut mensyaratkan makna al-umm adalah seorang ibu memiliki kemampuan dalam mendidik keluarganya; 5) Makna dan pemakaiannya, yaitu mencakup makna leksikal al-ma'na al-mu'jamy, makna kontekstual al-ma'na allafdzy dan makna istilah al-ma'na al-istilaby.

Taraf semantik gramatikal, erat hubungannya dengan tata bahasa yaitu morfologi dan sintaksis. Morfologi adalah ilmu yang menyangkut struktur internal kata. Dalam Bahasa Arab sama dengan ilm ash-sharf, yaitu tata hubungan pembentukan kata. Makna sintaksis yang dalam Bahasa Arab merupakan kajian ilm an-nahw adalah makna atas hubungan gramatikal di luar batas kata, yaitu dalam satuan yang disebut kalimat.

Berdasarkan dua taraf di atas, cara yang digunakan untuk menemukan dan menjelaskan suatu makna, dapat dilakukan dengan empat cara, yakni: pertama, berdasarkan kata; kedua, berdasarkan kalimat; ketiga, berdasarkan struktur yang digunakan; dan keempat, berdasarkan proses komunikasi yang dibangun. Hubungannya dengan tafsir al-Qur'an secara umum, cara yang digunakan mengikuti langkah-langkah yaitu; 1) mengumpulkan penggunaan kata yang hendak dibahas dalam sejumlah besar puisi pra Islam; 2) meneliti penggunaan kata yang hendak dibahas pada sîrab nabawiyah; 3) membandingkannya dengan kamus bahasa Arab yang relevan terhadap kata yang hendak dibahas sesuai dengan penggunaan kata itu pada masanya; dan 4) meneliti penggunaan kata yang dibahas pada ayat al-Qur'an.

Metode analisis semantik memiliki keistimewaan karena seorang pembaca dapat mengetahui pergeseran makna kata, dari satu generasi ke generasi berikutnya. Keistimewaan tersebut sekaligus juga menjadi kelemahan, karena untuk mendialogkan al-Qur'an dengan realita saat ini, perlu analisis yang lebih mendalam untuk menentukan makna mana yang sesuai untuk digunakan. AlQur'an dapat dianalisis berdasarkan puisi pra-Islam, berdasarkan sîrah nabawiyah, berdasarkan kamus, berdasarkan penggunaannya di dalam al-Qur'an itu sendiri, atau menggabungkan keempatnya demi menemukan satu arti yang bisa dicakup oleh keempatnya. Kata dîn yang berarti agama, pada masa pra-Islam dipahami sebagai sulthân atau kekuasaan. Saat itu mereka berada di bawah kendali orangorang kuat yang memegang kekuasaan yang mewajibkan mereka untuk menyembah berhala. Saat ini, kata dîn dapat diartikan sebagai ketaatan dan ketundukan. Dalam surat al-Fatihah (QS. 1: 4), kata tersebut sering diartikan sebagai pembalasan, tetapi dalam surat al-Kafirun (QS. 109: 6), kata tersebut diartikan sebagai agama, dengan latar historis adalah ajakan orang-orang Quraisy kepada Nabi Muhammad SAW untuk berbagi dalam menyembah Tuhan. Suyuthi memahami kata tersebut sebagaimana terdapat dalam surat al-Fatihah (QS. 1: 4), yaitu pembalasan. Kata 'pembalasan' mengandung pertanyaan; Apa balasanku yang taat kepada-Mu dan apa balasan mereka yang tidak taat kepadaMu? Jawab-Nya, balasan yang taat adalah kemenangan (QS. 110: 1) dan balasan yang tidak taat adalah kecelakaan (QS. 111: 1). Berarti, kata dîn, baik yang 
dipahami saat itu ataupun saat ini, bermuara pada adanya satu pihak maha kuat dan pihak lain sangat lemah.

Cara lain yang bisa digunakan adalah 1) meneliti penggunaan kata yang dibahas berdasarkan bahasa; 2) meneliti penggunaan kata yang dibahas berdasarkan adat; 3) meneliti penggunaan kata yang dibahas berdasarkan syara; dan 4) meneliti penggunaan kata yang dibahas pada ayat al-Qur'an. Kata shalât misalnya, secara bahasa berarti doa, tetapi secara syar'i berarti ucapan-ucapan dan gerakan-gerakan tertentu. Kata faqiha, secara bahasa berarti memahami semua bidang ilmu, tetapi secara adat dibatasi hanya pada bidang hukum Islam (Fakir, 2007: 91-96). Dalam al-Qur'an, kata ini kembali digunakan dalam konteks umum, dan seringkali digandengkan dengan kata qalb, sebagaimana dalam surat al-A'raf (QS. [7]: 179).

\section{b. Metode analisis tematik}

Dalam ilmu tafsir, metode tematik dikenal dengan tafsîr mawdlî̀iy. Tafsîr mawdlû'iy adalah penafsiran, penjelasan, komentar atas al-Qur'an mengenai suatu tema/topik kehidupan (teologi, etika sosial, atau kealaman) yang diambil dari pengertian ayat dan/atau surat dalam al-Qur'an untuk menjelaskan kedudukan hukumnya. Ayat-ayat dalam al-Qur'an dihimpun ke dalam satu surat atau lebih yang antara satu dengan lainnya dapat dikelompokan pada bidang pembahasan tertentu.

Metode tematik ingin menegaskan bahwa dalam ayat-ayat al-Qur'an tidak ada yang bertentangan antara satu dengan yang lainnya. Prinsip dasarnya adalah kesatuan makna dan kemudian membiarkan al-Qur'an berbicara tentang bidang tersebut. Ketika dalam satu tema, masih ditemukan ayat yang bertentangan maka mufassir yang menggunakan metode ini belum berhasil. Metode tematik dapat dibagi ke dalam dua, yakni metode tematik berdasarkan surat dan metode tematik berdasarkan subjek atau tema tertentu. Metode pertama membahas hal/kasus yang ditemukan pada satu surat saja, kemudian dibahas pokok-pokok pikiran dari surat tersebut. Metode kedua yaitu penentuan tema tidak dibatasi pada satu surat, tetapi dari seluruh surat yang ada dalam al-Qur'an, yang dipilih secara purposif.

Ada beberapa asumsi dasar tentang pengembangan (metode) tafsîr mawdlû'iy dalam khazanah ilmu tafsir al-Qur'an, yakni: 1) integritas pesan qurani, yakni kualitas atau keadaannya membentuk satu kesatuan yang utuh; 2) yufassiru ba'dhubu ba'dhan (sebagian menafsirkan sebagian yang lain); 3) di satu sisi, teks atau nash itu terbatas. Oleh karena itu, hukum yang menjelaskan dan mengelaborasinya pun terbatas. Di sisi lain problem kemanusiaan dan perkembangan ilmu pengetahuan tidak terbatas. Oleh sebab itu, mereka berkembang terus secara dinamis, serta tidak ditemukan referensinya dalam teks al-Qur'an; 4) problem penafsiran lebih menitikberatkan pada pendekatan analisis redaksi. Pendekatan ini, meskipun di satu sisi banyak memberikan informasi pemahaman tentang makna suatu teks, akan tetapi di sisi lain, pendekatan ini 
tidak menyajikan al-Qur'an secara utuh (integral) dan tidak dapat merespons tuntutan persoalan aktual yang berkembang dalam masyarakat (Muslih, 2008: 114-5).

Langkah-langkah metodologi tafsîr mawdlü'iy menurut al-Farmawi yaitu; 1) menetapkan masalah (tema, konsep, atau topik) yang akan dibahas; 2) menghimpun ayat-ayat yang berkaitan dengan masalah (tema, konsep, atau topik) tersebut, 3) menyusun kronologis ayat sesuai dengan masa turunnya, disertai pengetahuan tentang asbâb an-nu₹̂́l-nya; 4) memahami korelasi atau munâsabah ayat-ayat tersebut dalam suratnya masing-masing; 5) menyusun pembahasan dalam kerangka yang sistematis, sempurna, dan utuh; 6) melengkapi pembahasan dengan hadis-hadis yang relevan dengan pokok bahasan, dan 7) mempelajari ayat-ayat tersebut secara keseluruhan dengan jalan menghimpun ayat-ayatnya yang memiliki pengertian yang sama, mengkompromikan antara yang umum dan khusus, antara yang mutlaq dan muqayyad, atau ayat-ayat yang tampak (seolaholah) bertentangan/kontradiktif, sehingga semuanya bertemu dalam satu muara, tanpa perbedaan dan pemaksaan (Maragustam Siregar, http:// maragustamsiregar.wordpress.com/2011/01/10/)

Tafsìr mawdlûiy membangun keuniversalan dan kekomprehensivan alQur'an. Penafsiran tidak lagi bersifat parsial, tetapi menyeluruh dalam satu kesatuan makna "wibdah mawdlû'iyyah". Metode tafsîr mawdlû'iy memiliki beberapa keistimewaan. Pertama, metode ini memungkinkan menghasilkan penafsiran yang lebih bisa diterima, karena menafsirkan al-Qur'an dengan al-Qur'an, baik berdasarkan riwayat atau pun dirayat. Kedua, metode ini memungkinkan untuk menolak anggapan adanya ayat yang saling bertentangan. Keistimewaan tersebut tidak ada artinya, kecuali memperhatikan; 1) pemilihan tema atau topik hendaknya berdasarkan kebutuhan yang sesuai; 2) menyusun kronologis ayat

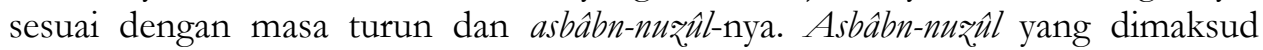
adalah segala aspek historis yang berkaitan dengan turunnya ayat; 3) melengkapi pembahasan dengan hadis-hadis yang relevan dengan pokok bahasan. Al-Qur'an dan hadis memiliki kedudukan yang sama, sebagai naskah yang di dalamnya tertulis sumber ajaran dan petunjuk bagi manusia. Oleh karena itu, metode analisis untuk meneliti al-Qur'an sama kedudukannya dengan metode analisis hadis. Berarti metode yang dipilih baik untuk meneliti al-Qur'an maupun untuk meneliti hadisnya harus sama.

\section{c. Metode analisis hermeneutik}

Secara historis, hermeneutik memiliki enam bentuk. Pertama, teori eksegesis Bibel. Kedua, metodologi filologi secara umum. Ketiga, ilmu pemahaman linguistik. Keempat, fondasi metodologis geisteswessenshaften. Kelima, fenomenologi eksistensi dan pemahaman eksistensial. Keenam, sistem interpretasi (Palmer, 2005: 38).

Teori eksegesis Bibel digunakan untuk menganalisis kitab suci Bibel, kemudian meluas dengan mengarah kepada teks kitab suci nonbibel. Oleh 
karena itu, pengertian umum hermeneutik tetap menunjuk pada teori tentang penafsiran kitab suci (Palmer, 2005: 40). Bukan hanya pada kitab suci tertentu, tetapi semua kitab suci, termasuk al-Qur'an.

Hermeneutik dan tafsir memiliki peranan yang sama pentingnya. Keduanya membicarakan makna kitab suci. Hermeneutik adalah sebuah metode interpretasi untuk memahami Bibel, sedangkan tafsir untuk memahami alQur'an. Menurut Komarudin (1996: 126), walaupun keduanya lahir dari masyarakat yang berbeda, sebagai ilmu, hermeneutik bisa digunakan untuk alQur'an dengan penyesuaian-penyesuaian tertentu. Perbedaannya, hermeneutik untuk al-Qur'an bukan untuk menguji keotentikan dan keaslian al-Qur'an, tetapi untuk meneliti makna yang dianggap lebih mendekati makna sebenarnya yang diinginkan Tuhan.

Baidan (2005: 77-84) membedakan keduanya, bahwa; (a) dalam hermeneutik, utusan memiliki kewenangan penuh untuk menyampaikan pesan yang dibawanya sesuai dengan bahasa yang dimengerti oleh umat yang akan menerima pesan tersebut, dalam tafsir utusan hanyalah penerus Tuhan; (b) dalam prosesnya, hermeneutik tidak mementingkan urutan prosedural, dalam tafsir hal tersebut justru sangat diperhatikan; (c) ruang lingkup kajian hermeneutik berkisar pada tiga hal, yaitu teks, interpreter, dan audiens; dalam tafsir "melibatkan Tuhan".

Secara epistemologis, Supena (2008: 51-55) menguraikan kekuatan dan kelemahan hermeneutik dan tafsir, yaitu; 1) Keunggulan tafsir terletak pada penekanannya atas watak objektif sehingga produk penafsiran terhadap alQur'an tidak semena-mena. Kelemahan tafsir; Pertama, tafsir dianggap tidak mampu memenuhi struktur triadik berupa hubungan dialektis antara teks, penafsir, dan realita. Kedua, objektivitas tafsir yang lebih menekankan lahiriah teks ternyata dapat mempersempit ruang pemahaman terhadap konteks alQur'an. Ketiga, fakta perkembangan penafsiran, seringkali memperlakukan ayat secara terisolasi. Keempat, tafsir sering melahirkan produk yang bersifat tetap, abadi, dan tunggal; 2) Keunggulan hermeneutik adalah watak penafsirannya yang terbuka, toleran, dan fleksibel. Hal tersebut menyebabkan produk penafsiran tidak sakral. Kelemahan hermeneutik yaitu tidak adanya penafsiran yang final.

Di kalangan akademisi Indonesia, tafsir al-Qur'an berbasis hermeneutik semakin mengemuka. Hal ini karena, metode tersebut dipandang dapat mengembangkan nilai kontekstualitas teks/nash yang diteliti. Hermeneutik berusaha menggali makna dengan mempertimbangkan horizon/cakrawala/ wawasan penafsir yang memengaruhi/melingkupi teks. Horizon adalah medan pencarian makna antara teks, pengarang, dan pembaca (mufassir). Metode hermeneutik sangat peduli dengan hubungan dialektik (dialog yang bertujuan untuk mendapatkan kepastian dan menghilangkan keraguan) antara teks, mufassir, dan realitas dalam menentukan makna. Dari proses dialog antara teks, mufassir, dan realitas (yang melingkupi teks) dapat menghasilkan kontekstualitas penafsiran. Meskipun hermeneutika termasuk teori mutakhir dalam upaya untuk 
melakukan kontekstualisasi al-Qur'an, namun teori, ini secara umum, sudah dilakukan dalam ilmu tafsir al-Qur'an klasik. Essack mengemukakan beberapa buktinya, yaitu; 1) adanya kajian atas asbâb an-nuحûl dan nâsik-h-mansûkh; 2) adanya perbedaan antara pemahaman aktual terhadap al-Qur'an dengan aturan, teori, atau metode penafsiran yang mengaturnya sejak munculnya berbagai literatur tafsir yang disusun sesuai dengan kerangka prinsip-prinsip ilmu tafsir; 3) tafsir klasik/tradisional senantiasa memasukkan kategori-kategori, misalnya tafsir Syi'ah, tafsir Mu'tazilah, tafsir hukum, dan tafsir filsafat. Hal itu menunjukkan ada pengklasifikasian kelompok, ideologi, periode, maupun horizon sosial tertentu dari karya tafsir. Semua itu menunjukkan sebuah pola hermeneutika (Rosadisastra, 2007: 132).

Langkah-langkah metodologi hermeneutik dalam menafsirkan teks alQur'an, yaitu; 1) memahami teks melalui aspek kebahasaan. Aspek ini memiliki tiga tipe, yakni morfologis, leksikologi, dan sintaksis; 2) melihat aspek historis terciptanya teks. Ia bukan sekedar peristiwa yang melatarbelakangi munculnya suatu teks, tetapi lebih tepatnya adalah latar sosial historis di masa teks itu muncul; 3) melakukan kontekstualisasi ayat yang ditafsirkan dengan aspek realitas kehidupan yang berkembang di masa mufasir, masa kini dan masa yang akan datang; 4) melakukan kritik teks. Kritik teks adalah perpindahan dari teks kebenaran nash al-haqîqah menuju kebenaran teks haqîqat al-nash. Jika sebuah teks menciptakan kebenaran atau memiliki kerealitasannya, teks tersebut harus diberlakukan sebagai sebuah peristiwa. Artinya, selalu berusaha membuka dimensi-dimensi atau membangun kemungkinan-kemungkinan, membebaskan belenggu, atau memikirkan fungsi dan manfaat teks itu.

Menurut Magestari (1998: 148-149), ada beberapa asumsi dasar yang harus dipegang oleh mufassir dalam rangka menelusuri makna yang terkandung dalam al-Qur'an menurut hermeneutik; 1) telaah atas hakikat teks yakni, teks diperlakukan sebagai sesuatu yang mandiri, dilepaskan dari pengarangnya, waktu terciptanya, dan konteks kebudayaan pengarang maupun kebudayaan yang berkembang dalam ruang dan waktu ketika teks itu diucapkan/dibaca. Karena itu, wujud teks adalah tulisan, dan yang ditulis adalah bahasa, maka yang menjadi pusat perhatiannya adalah hakikat bahasa; 2) proses apresiasi, yaitu proses yang mengandaikan bahwa pembaca/peneliti mengerti akan dunia teks dan mampu membaca teks. Hal ini ditunjukan tidak hanya pembaca/peneliti itu bisa kembali pada dunianya sendiri, tetapi juga menciptakan dunia baru bagi dirinya. Dengan kata lain, mufassir memahami lebih dulu tentang dirinya sendiri, mengerti dirinya secara lain, dan mengerti dirinya sediri setelah ia mengerti akan "dunia" teks; 3) proses interpretasi, yakni menempatkan antara pembaca/peneliti/mufassir ketika berhadapan dengan teks berdasarkan waktu tertentu. Mufassir berada pada situasi-masa yang dikenal sebagai situasi hermeneutik. Mufassir senantiasa sadar bahwa dirinya berada di antara masa lalu (saat teks diciptakan), masa kini (saat mufassir berada) dan masa depan (saat mufassir tiada), serta di antara yang dikenal dan yang asing. Di dalam situasi ini, pembaca/peneliti/penafsir menerka, 
menginterpretasikan arti yang tampak, dan mencoba memahami arti yang tidak tampak (tersembunyi). Arti yang tidak tampak itu menjadi tersembunyi oleh unsur atau jarak waktu, geografis, budaya, atau bahkan spiritual. Dengan demikian, proses interpretasi itu seolah-olah menjembatani unsur dari jarak itu. Atas dasar ini, teks disebut sebagai sesuatu yang "mandiri".

\section{Metode Penelitian al-Qur'an}

\section{a. Analisis teks dan terjemah}

Teks al-Qur'an merupakan tulisan yang ditetapkan pada masa khalifah Utsman ibn 'Affan, maka disebut Mushhaf Utsmani. Terjemah merupakan upaya para pemerhati al-Qur'an dalam mengalihkan bahasa al-Qur'an ke dalam bahasa lain, setelah al-Qur'an disebarluaskan ke berbagai bangsa dan negara.

Para peneliti al-Qur'an umumnya sepakat bahwa teks al-Qur'an itu adalah teks yang sudah baku (Rasm Utsmani). Terjemah pun dianggap sudah baku, sebab penyesuaian dengan bahasa daerah biasanya dikelola oleh lembaga khusus/resmi penerjemah al-Qur'an setempat.

Terjemah dapat dipahami sebagai sebuah proses pengalihan bahasa asal ke bahasa sasaran dengan mengungkapkan kembali bahasa asal tersebut dengan menggunakan bahasa sasaran. Proses pengalihan bahasa ini, bisa berupa berpindahan kata (terjemah kata) atau juga perpindahan makna (terjemah makna). Dari proses ini, penerjemah harus menguasai setidaknya dua bahasa, yaitu bahasa asal dan bahasa sasaran. Hanya karena ada lembaga khusus tersebut, dalam hal terjemah biasanya sama (meskipun kadang-kadang ada perbedaan). Hal yang membedakannya adalah penafsiran atas terjemah. Salah satu persoalan penafsiran atas terjemah ini adalah ketika menentukan kata asal dari teks. Sejumlah kata yang digunakan dalam ayat-ayat kisah dapat dipahami berdasarkan bahasa yang digunakan pada saat turunnya Al-Qur'an dan/atau berdasarkan kamus bahasa penerjemah yang berkembang saat ini yang penting tujuan terjemah tercapai. Tujuan penerjemahan al-Qur'an adalah memindahkan bahasa asal ke dalam bahasa sasaran agar dipahami oleh penggunan bahasa sasaran secara benar.

\section{b. Analisis $A s b a ̂ b$ an-nuzûl}

Asbâb an-nuzûul artinya "sebab-sebab turun". Secara istilah, ia adalah sesuatu yang dengan sebabnya turun suatu ayat atau beberapa ayat yang mengandung sebab itu, atau memberi jawaban terhadap sebab itu, atau menerangkan hukumnya pada masa terjadinya sebab tersebut (Shaleh, 1988: 132). Sebab dalam konteks asbâb an-nuðûl tidak sama dengan sebab dalam ketentuan kausalitas, bahwa bila tidak ada sebab, al-Qur'an tidak akan turun. Sebab dalam konteks asbâb an-nu₹ûl adalah peristiwa yang menjadi petunjuk hukum berkaitan dengan turunnya suatu ayat dalam al-Qur'an. Oleh karena itu, tidak semua ayat-ayat al-Qur'an harus memiliki "sebab turun" dalam pengertian khusus meskipun semuanya memiliki "sebab turun" dalam pengertian umum. 
Kerumitan lain dalam asbâb an-nuð̂ul adalah ketika penafsir mencoba menentukan suatu ayat dengan pertimbangan redaksi yang umum namun memiliki sebab turun yang khusus. Hal tersebut dapat dipahami berdasarkan keumuman lafal atau kekhususan sebab. Namun tidak dapat dihindari bahwa asbâb an-nu₹ûlmempengaruhi berlakunya keumuman redaksi yang digunakan alQur'an. Berarti ada peran dan fungsi kekhususan suatu dalil terhadap keumumannya. Bila tidak demikian, analisis berdasarkan asbâb an-nuz̧ûl menjadi tidak penting.

Langkah-langkah yang dapat ditempuh ketika berupaya memberlakukan sebuah ayat, yaitu: 1) memberlakukan ayat itu secara umum; dan 2) memberlakukan ayat itu secara khusus, terutama ketika keumumannya bertentangan dengan keumuman pada nash yang lain. Berhubungan dengan langkah yang kedua, ada beberapa strategi yang dapat ditempuh, yakni: (a) memperhatikan posisi ayat yang menggunakan redaksi umum terhadap sebab khusus, atau redaksi khusus dengan sebab khusus, (b) apabila menggunakan redaksi yang umum, maka ayat tersebut dapat berlaku umum tanpa pengecualian atau berlaku umum dengan pengecualian, (c) ketika ayat tersebut dapat berlaku umum dengan pengecualian, tentukan hal-hal yang mungkin menjadi pengecualiannya, (d) memperhatikan bahwa pengecualian tersebut bertentangan tidak bertentangan dengan nash lain. Strategi di atas ingin mengatakan bahwa suatu ayat, dengan keumumannya, bisa menjangkau segala hal yang terjadi nanti, dan dengan kekhususannya bisa membatasi dirinya dan ayat lain.

\section{c. Analisis Munâsabah}

Secara etimologi, munâsabah adalah kebercocokan atau keberdekatan atau keberdampingan (al-muqârabah wa al-musyâkalah). Menurut istilah, munâsabah adalah segi-segi hubungan antara suatu kalimat dengan kalimat lain dalam satu ayat, antara satu ayat dengan ayat lain dalam banyak ayat, atau antara satu surat dengan surat lainnya (al-Qaththan, 1973: 77).

Berdasarkan dua pengertian di atas, munâsabah terbagi dua, yakni: pertama, munâsabah yang disusun berdasarkan kronologis turunnya, dan ini membutuhkan pengetahuan yang mendalam tentang kronologis dan sebab-sebab turunnya. Kedua, munâsabah yang disusun berdasarkan Mushhaf Utsmani. Berdasarkan kronologis, dakwah Rasulullah SAW diawali dengan penanaman aqidah untuk semua manusia, kemudian penegakan hukum ibadah untuk orang-orang yang beriman. Berdasarkan munâsabah Mushhaf Utsmani diawali dengan penegakan hukum ibadah bagi orang-orang yang beriman, dilanjutkan dengan aqidah. Asumsi dasarnya mereka adalah umat yang sudah memiliki aqidah.

Langkah-langkah penelitian al-Qur'an berdasarkan munâsabah yaitu: 1) melihat tujuan yang akan dicapai oleh suatu surat, 2) memperhatikan hal-hal yang akan diperlukan untuk mencapai tujuan tersebut, 3) memperhatikan tingkatan tujuan tersebut dalam hal dekat atau jauhnya untuk mencapai tujuan yang dimaksud, 4) memperhatikan keharusan-keharusan yang dituntut oleh aturan 
keindahan bahasa yang dapat menimbulkan perhatian untuk memahami uraianuraian dalam suatu surat.

Pemahaman al-Qur'an melalui penelitian munâsabah, dapat dilakukan melalui empat cara, yakni: 1) membaca teks (al-ibârab); 2) menangkap isyarat (alisyârah) teks; 3) merasakan kehalusan bahasanya (al-lathâif); 4) memahami hakikatnya teks (al-haqâiq).

\section{d. Analisis nilai dan wacana tafsir.}

Sebagai sebuah analisis tentang wacana (kandungan), tafsir yang dilakukan oleh para mufassir terhadap ayat al-Qur'an beragam. Keragaman terjadi karena mufassir memiliki latar belakang, ilmu pengetahuan, dan madzhab yang berbeda dan secara langsung atau tidak dapat membentuk kepribadian seorang mufassir. Para peneliti al-Qur'an di samping memposisikan dirinya sebagai mufassirjuga sering mencari penjelasan dari mufassir lain yang telah populer. Penelaahan wacana tafsir dari para mufassirpopuler itu akhirnya banyak mewarnai penjelasan peneliti/mufasir. Karena itu, penelitian terhadap al-Qur'an, misalnya "Konsep Pendidikan menurut al-Qur'an", pada akhirnya akan bermuara pada "Konsep Pendidikan dalam al-Qur'an menurut Para Mufasir'.

\section{Pengembangan Metode Penelitian Pendidikan Islam}

Dengan memperhatiakan prinsip dasar dan mengacu pada metode dan langkah praktis penelitian al-Qur'an dapat dibuat model pengembangan landasan teologis dan metodologis penelitian pendidikan Islam, yaitu

\begin{tabular}{|c|c|c|c|c|c|}
\hline Langkah & $\mathrm{D}$ & $\mathrm{E}$ & $\mathrm{F}$ & $\mathrm{G}$ & $\mathrm{H}$ \\
\hline Metode & $\mathrm{AD}$ & $\mathrm{AE}$ & $\mathrm{AF}$ & $\mathrm{AG}$ & $\mathrm{AH}$ \\
\hline $\mathrm{B}$ & $\mathrm{BD}$ & $\mathrm{BE}$ & $\mathrm{BF}$ & $\mathrm{BG}$ & $\mathrm{BH}$ \\
\hline $\mathrm{C}$ & $\mathrm{CD}$ & $\mathrm{CE}$ & $\mathrm{CF}$ & $\mathrm{CG}$ & $\mathrm{CH}$ \\
\hline
\end{tabular}

Keterangan :

- Metode analisis terhadap ayat-ayat al-Qur'an terbagi tiga, yakni:
a. Metode analisis semantik (A)
b. Metode analisis tematik (B)
c. Metode analisis hermeneutik (C)

- Langkah-langkah metodologis penelitian al-Qur'an adalah:
a. teks dan terjemah (D)
b. asbâb an-nuzûl (E)
c. munâsabah $(\mathrm{F})$
d. nilai dan wacana tafsir $(\mathrm{G})$

Dari delapan variabel di atas diperoleh setidaknya lima belas macam metode penelitian pendidikan Islam, yaitu:

1. Metode analisis semantik berbasis teks dan terjemah (AD);

2. Metode analisis semantik berbasis (AE); 
3. Metode analisis semantik berbasis munâsabah (AF);

4. Metode analisis semantik berbasis nilai dan wacana tafsir (AG);

5. Metode analisis semantik berbasis pedagogis $(\mathrm{AH})$;

6. Metode analisis tematik berbasis teks dan terjemah (BD);

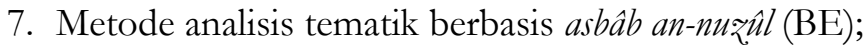

8. Metode analisis tematik berbasis munâsabah (BF);

9. Metode analisis tematik berbasis nilai (BG);

10. Metode analisis tematik berbasis pedagogis $(\mathrm{BH})$;

11. Metode analisis hermeneutik berbasis teks dan terjemah (CD);

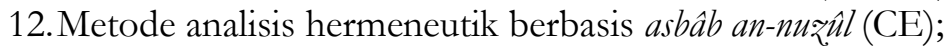

13. Metode analisis hermeneutik berbasis munâsabah (CF);

14. Metode analisis hermeneutik berbasis nilai (CG);

\section{a. Metode penelitian berbasis kata dan terjemah}

Model ini bermaksud menelaah makna dengan berbasis pada kata-kata yang digunakan dalam al-Qur'an. Kata-kata dalam al-Qur'an tidak ditelusuri berdasarkan konteks penggunaannya dalam misalnya sya'ir jâhiliyah dan sîrah nabawiyah, tetapi ditelusuri kedudukan dan kegunaan suatu kata dalam al-Qur'an. Untuk itu perlu diketahui pelbagai macam redaksi ayat dalam al-Qur'an. AlZarkasyi (1988: 147-169) mengemukakan ada delapan macam redaksi ayat-ayat al-Qur'an, yaitu:

1. Perbedaan tata letak kata dalam kalimat, seperti Surat al-Baqarah (QS. 2:120) dengan Surat al-An'am (QS. Al-An'am, [6]: 71);

2. Pengurangan dan penambahan huruf, seperti Surat al-Baqarah (QS. 2:6) dengan Surat Yasin ([36]: 10);

3. Pengawalan dan peng-akhiran, seperti Surat al-Baqarah (QS. [2]: 129) dengan Surat al-Jumu'ah (QS. [62]: 2);

4. Perbedaan nakirah dan ma'rifah, seperti Surat Fushilat ([41]: 36) dengan Surat al-a'raf (QS. [7]: 200);

5. Perbedaan bentuk jama' dan bentuk tanggal, seperti Surat al-Baqarah (QS. [2]: 80) dengan Surat Ali Imran (QS. [3]: 4);

6. Perbedaan penggunaan huruf kata depan, seperti Surat al-Baqarah (QS. [2]: 58) dengan Surat al-a'raf (QS. [7]: 161);

7. Perbedaan penggunaan kosa-kata, seperti Surat al-Baqarah (QS. [2]: 170) dengan Surat Luqman (QS. [31]: 21);

8. Perbedaan penggunaan idgham, seperti Surat al-Hasyr (QS. [59]: 4) dengan Surat al-Anfal (QS. [8]: 13).

Berdasarkan perbedaan redaksi, peneliti setidaknya harus menguasai empat hal, yakni: pertama, kosa-kata (mufradât); kedua, sintaksis (ilm an-nahw); ketiga, morfologi (ilm ash-sharf); dan keempat, etimologi (ilm al-isytiqâq).

1. Kosa-kata

Di dalam al-Qur'an dikenal adanya kosa-kata haqîqy dan majâzy atau kosakata yang berkonotasi metaforis, misalnya, kata ummatun yang terulang sebanyak 
49 kali dalam al-Qur'an. Kata ini memiliki berbagai makna konotasi, seperti orang banyak, ajaran, kebiasaan yang berlaku dalam suatu agama, dan memiliki sifat-sifat keutamaan lainnya. Kata ini di antaranya ditemukan dalam surat alZukhruf (QS.[43]: 22), dengan redaksi sebagai berikut.

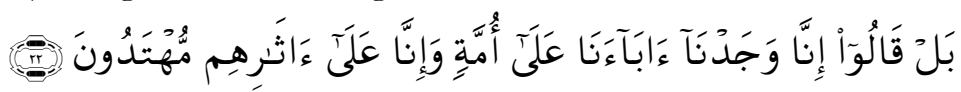

Berkenaan dengan ayat di atas, dapat dirumuskan beberapa terjemah atas kata ummatun, yaitu, “...Sesungguhnya kami mendapati bapak-bapak kami menganut suatu agama, dan sesungguhnya kami orang-orang yang mendapat petunjuk dengan mengikuti jejak mereka." Atau, “...Sesungguhnya kami mendapati bapak-bapak kami di atas suatu ummat, dan sesungguhnya kami orang-orang yang mendapat petunjuk dengan mengikuti jejak mereka." (Baidan, 2005: 337). Kata umm dapat berarti “ibu” namun dalam surat al-Qari'ah (QS. [101]: 8-9) dapat diartikan sebagai “tempat kembali”. Kedua arti tersebut dapat didekati dengan asumsi, bahwa ibu adalah tempat kembali.

2. Sintaksis (Ilm an-Nabwu)

Di dalam bahasa al-Qur'an, dikenal ada tata letak dan ada perubahan fungsi yang dapat memengaruhi makna kalimat. Contoh tata letak seperti dalam surat al-Baqarah (QS. [2]: 127) dengan redaksi sebagai berikut.

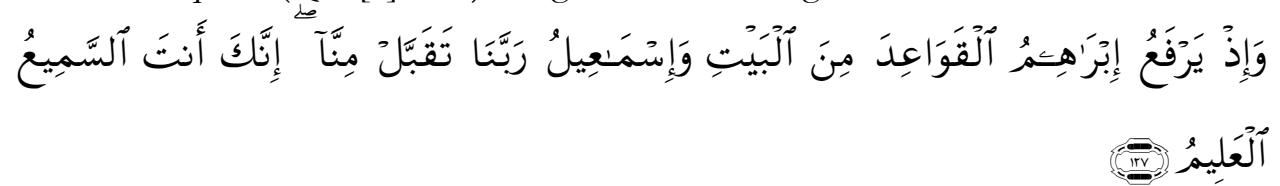

Ayat di atas memiliki dua subjek, yaitu Ibrahim dan Ismail. Objek dari ayat tersebut tidak ditempatkan setelah keduanya, tetapi ditempatkan di antara keduanya. Karena itu, ayat di atas sering dipahami bahwa Ibrahim-lah yang menjadi subjek utama bukan Ismail. Kekeliruan semacam ini sering terjadi, misal dalam kasus surat Fathir, (QS. [35]: 28 yaitu;

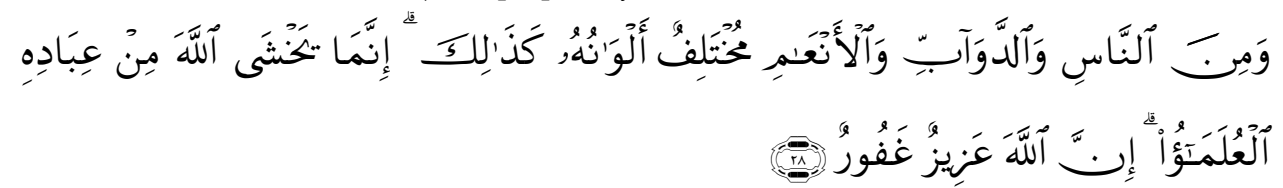

Pada ayat di atas, kata ulama ditempatkan di akhir pernyataan. Umumnya redaksi dalam bahasa Arab akan menempatkan subjek sebelum objek. Tetapi dalam kalimat di atas adalah sebaliknya, yaitu dengan menempatkan objek setelah subjek. Bila menggunakan penempatan yang pertama, ayat di atas akan dimaknai, "...Di antara hamba-hamba Allah, hanya ulama yang takut kepadaNya..." Bila menggunakan penempatan yang kedua, akan dimaknai, “...Di antara hamba-hamba Allah, hanya ulama yang ditakuti-Nya...” (Baidan, 2005: 338-340). 


\section{Morfologi (Ilm ash-sharf)}

Di dalam bahasa al-Qur'an dikenal ada bentuk kata dan pembinaannya yang akan memengaruhi makna kalimat. Dalam basmalah, kata rahmân dan rahîm berasal dari kata yang sama, yaitu rabima dengan wazan yang berbeda. Bentuk dan pembinaan pertama mengikuti wazan fa'lân sedangkan yang kedua mengikuti wazan fa'̂̀l. Kedua wazan tersebut berperan dalam memengaruhi makna kalimat. Wazan pertama sering dimaknai sebagai sesuatu yang berkesinambungan, sedangkan yang kedua sebagai sesuatu yang temporal. Kekeliruan seperti ini sering terjadi, misal dalam kasus surat al-Isra, [17]: 71 yaitu pada kata imâm. Dalam sejumlah riwayat, kata imam sering dimaknai dengan pemimpin atau catatan amal. Ada juga yang berpendapat bahwa kata imâm adalah jamak dari kata umm yang berarti ibu. Dengan demikian, ayat di atas berkonotasi bahwa pada hari kiamat nanti setiap manusia akan dipanggil berdasarkan nama ibunya. Ini biasanya dipergunakan dalam rangka menghormati nabi Isa yang menyatakan kemuliaan Hasan, atau tidak mempermalukan anak zina (Baidan, 2005: 340-341).

\section{Etimologi ('Ilm al-isytiqâq')}

Di dalam bahasa al-Qur'an sering dikenal ada sejumlah kosa-kata yang mirip dalam tulisan dan bacaan (al-isytiqâq). Bila ditelusuri, kemiripan ini terkadang memiliki asal-usul yang berbeda. Oleh karena itu dapat memengaruhi makna kalimat. Misalnya kata albâbun yang terulang sebanyak 21 kali. Kata ini memiliki asal-usul yang berbeda-beda. Lima kali terulang sebagai kata tunggal dengan jamaknya abwâbun yang berarti "pintu", dan enam belas kali terulang sebagai kata jamak dengan tunggalnya lubbun yang berarti "akal" (Baidan, 2005: 343).

Isytiqâq terbagi empat, yakni: 1) isytiqâq ashghar; 2) isytiqâq akbar; 3) isytiqâq kabîr; dan 4) isytiqâq kubbâr. Isytiqâq ashghar merupakan yang paling umum, karena berkaitan dengan tiga huruf asli dalam bahasa Arab. Isytiqâq ashghar memiliki tiga cabang, yakni: (a) asal isytiqâq yang membicarakan tentang awal dari suatu kata, bisa fi'il atau mashdar, (b) Isytiqâq af'âl yang berkaitan dengan bentuk-bentuk fi'il, bisa mujarrad, mąî̀d, tsulâsi, dan rubâ'i; (c) Isytiqâq asma yang berkaitan dengan bentuk-bentuk isim. Contoh isytiqâq ini adalah kata yang terdiri atas 'ain, lâm, dan mîm, yang membentuk kata 'alima yang memiliki arti menemukan, menampakkan, dan menjelaskan. Setelah itu terbentuklah kata-kata seperti 'allama, 'allamna, 'álim, dan muta'allim.

Isytiqaq akbar adalah asal-usul yang terjadi di antara dua kata yang sesuai dalam maknanya dan sama dalam huruf aslinya namun bukan urutan katanya. Misalnya kata yang terdiri atas sîn mîm lâm; mîm, sîn, lâm; sîn, lâm, mîm; mîm, lâm, sîn; lâm, mîm, sîn; lâm, mîm, dan sîn. Secara umum mereka memiliki makna yang berkaitan, yaitu "pertemanan" dan "kelembutan".

Isytiqâq kabîr (ibdâl lughawy) yaitu asal-usul ketika menempatkan sesuatu pada tempat yang lain dalam kata, atau mengaitkan sebagian kumpulan tiga kata dengan sebagian arti lain secara umum yang tidak dikuatkan oleh kata itu sendiri 
tetapi dengan runtutan yang asal dan cabangnya bercabang setelahnya. Misalnya kata azza yang memiliki arti hazza. Isytiqâq kubbâr (nabt)-nya adalah mengembangkan, memutuskan, menjadikan, mengalirkan dan menyamakan sesuatu dalam satu batasan (Suryadinata, 2007: 195-201).

\section{b. Metode penelitian berbasis asbâb an-nuzûl}

Secara garis besar, asbâb an-nu₹̂ul melingkupi hal yang terstruktur dan yang kultur. Ruang lingkup pertama terhimpun dalam kitab-kitab klasik dalam bentuk hadis atau riwayat, sedangkan ruang lingkup kedua terhimpun dalam konteks yang meriwayatkannya (Nasuha, 2009: 3). Dalam pengembangannya, model ini berhubungan dengan beberapa hal yaitu: pertama, alasan al-Qur'an turun secara bertahap; kedua, metode penurunan ayat secara bertahap; ketiga, problematika antara kata umum dan sebab khusus; keempat, menentukan asbâb an-nuશûl; dan kelima, ayat yang turun berulang-ulang, satu ayat dengan beberapa sebab, beberapa ayat dengan satu sebab (Nasuha, 2009: 3).

1. Alasan al-Qur'an turun secara bertahap

Dalam sejarahnya, al-Qur'an turun secara bertahap hampir 22-23 tahun, diawali dengan surat al-'Alaq, (QS. [96]: 1-5) hingga surat al-Baqarah (QS. [2]: 281). Namun al-Qur'an tidak disusun berdasarkan tahapan-tahapan tersebut, tetapi berdasarkan tertib mushhaf, diawali dari surat al-Fatihah hingga surat alNas. Menurut al-Shabuny (1984: 60-61), turunnya al-Qur'an yang bertahap itu memiliki beberapa alasan: pertama, untuk meneguhkan hati Nabi SAW dalam berdakwah dan menghadapi celaan; kedua, meringangkan Nabi SAW dalam menerima wahyu; ketiga, menjelaskan langkah demi langkah dalam menetapkan hukum langit; keempat, memudahkan dalam memberi pemahaman kepada kaum muslimin; kelima, menjadikan al-Qur'an sejalan dengan kisah-kisah yang terjadi dan untuk mengingatkan itu semua; dan keenam, menjadi petunjuk bahwa alQur'an diturunkan dari Allah SWT.

2. Metode penurunan ayat secara bertahap

Shihab (1993: 34-38) membagi secara metodis turunnya wahyu dalam tiga periode, yaitu; (a) periode empat tahun pertama. Periode ini mengenai pendidikan kepada nabi Muhammad SAW, dalam membentuk kepribadiannya, pengetahuan dasar mengenai sifat dan kekuasaan Allah SW'T, dasar-dasar akhlak islamiyah, dan bantahan secara umum mengenai pandangan hidup masyarakat jahiliyah; (2) periode sembilan tahun kedua. Periode ini mengenai pemblokadean paham-paham jahiliyah; (3) periode sepuluh tahun ketiga. Periode ini mengenai nilai-nilai dalam kehidupan masyarakat. Bila periode tersebut dipilah ke dalam periode makkiyah dan madaniyah, maka periode madaniyah adalah periode tentang penanaman nilai-nilai dalam kehidupan masyarakat. Periode ini terjadi setelah terbentuknya kepribadian dan keimanan para sahabat dengan kuat, sehingga penanaman nilai-nilai tersebut berhasil. 
3. Problematika antara kata umum dan sebab khusus

Para ulama berbeda pendapat dalam menyikapi ayat yang turun dengan menggunakan redaksi yang umum tetapi dengan sebab yang khusus. Sebagian besar berpendapat bahwa yang dipegang adalah keumuman lafadz, sebagian kecil berpendapat, bahwa yang dipegang adalah kekhususan sebab. Kedua pendapat ini memiliki dalil yang cukup kuat dengan merujuk kepada sejumlah ayat alQur'an yang bila dipahami berdasarkan keumumannya akan keliru sehingga harus dengan kekhususannya, demikian juga dengan sejumlah ayat al-Qur'an yang harus dipahami dengan keumumannya dan bukan kekhususannya. Karena itu, kedua pendapat di atas memiliki keutamaan dan kelemahan. Pendekatan pertama akan mengarah kepada pemahaman teks semata. Hal ini akan melahirkan pemahaman yang sempit dan kaku. Pemahaman seperti ini akan sulit diterapkan pada situasi yang jauh berbeda. Pendekatan kedua akan mengarah kepada pemahaman konteks semata. Hal ini akan melahirkan pemahaman yang bebas, dengan tingkat subjektivitas mufassiryang sangat tinggi. Asbâb an-nuzûl yang ada, tidak lebih dari sekedar naskah pendek yang tidak lengkap dan tidak menggambarkan konteks yang utuh.

\section{Menentukan asbâb an-nu₹̣̂̂l}

Asbâb an-nu₹̣̂l adalah hadis yang berkaitan dengan peristiwa turunnya AlQur'an. Mengkaji asbâb an-nu₹ûl berarti mengkaji hadis, dengan tujuan mengidentifikasi hadis yang sesuai atau bertentangan dengan asbâb an-nu₹ûl. Para ulama berpendapat bahwa bila ditemukan hadis itu bertentangan, maka bisa diselesaikan dengan beberapa yaitu: pertama, mengkompromikan keduanya; kedua, me-nasakh salah satunya; ketiga, men-tarjîh hadis-hadis tersebut; dan keempat, membiarkan hadis itu hingga jelas.

Cara pertama mengharuskan peneliti untuk meneliti latar historis dengan segala fenomen-fenomen yang bisa mengkompromikan hadis-hadis tersebut, setelah itu baru difungsikan sebagai sebab turun. Cara kedua meneliti kronologis ayat yang lebih dulu ada terutama pada ayat yang diturunkannya berulang. Setelah diketahui ayat tertentu ternyata lebih dulu diturunkan dibanding dengan ayat lain, maka ayat itu yang digunakan. Cara ketiga ditempuh dengan cara meneliti kualitas para perawi yang meriwayatkannya sehingga diketahui kualitas hadisnya. Cara keempat mengamati secara alamiah status hadis yang dimaksud. Setelah diketahui statusnya maka hadis tersebut bisa difungsikan sebagai "sebab turun".

\section{c. Metode penelitian berbasis munâsabah}

Secara garis besar, munâsabah mencakup segala keterkaitan yang ada di dalam al-Qur'an mulai huruf, kata, kalimat, ayat, dan surat. Model penelitian ini bisa berbasis riwâyat, tetapi lebih dominan berbasis dirâyat, yaitu dengan melakukan kajian-kajian logis-dialektis antar variabel.

Dalam pengembangannya, ilmu ini memiliki keterkaitan dengan sejumlah alasan al-Qur'an disusun secara tertib mushaf dan dengan ayat yang disusun 
berulang-ulang. Tidak ada alasan yang kuat untuk menjelaskan mengapa alQur'an disusun seperti itu. Hanya beberapa hal bisa dijelaskan, misal, beberapa surat dalam al-Qur'an memiliki pembukaan yang sama, yakni diawali dengan tahmîd, tasbîh, dan huruf-huruf terputus. Surat yang diawali dengan tabmîd ada lima dan mereka berbeda di seperempat al-Qur'an, yaitu surat al-Fatihah, alAn'am, al-Kahfi, Saba, dan Fathir. Dalam arti ini, ayat dan/atau surat merupakan penjelasan atau kelanjutan dari ayat dan/atau surat sebelumnya.

Al-Biqa'i mengatakan bahwa semua surat di atas mengisyaratkan nikmatnikmat Allah SWT sesuai dengan perurutannya yaitu ayat pertama dalam surat alFatihah, diikuti ayat pertama dalam surat al-An'am. Ayat ini mengisyaratkan nikmat wujud di dunia dan segala potensi yang dianugerahkan di langit dan di bumi yang diperoleh melalui siang dan malam. Ayat pertama surat al-Kahfi mengisyaratkan nikmat pemeliharaan Allah SWT yang dianugerahkan secara aktual, baik melalui turunnya al-Qur'an maupun bentuk pemeliharaan lainya. Ayat pertama surat Saba mengisyaratkan nikmat Allah SWT di akhirat kelak, tempat manusia yang taat memperoleh kenikmatan abadi. Ayat pertama surat Fathir mengisyaratkan nikmat Allah SWT yang abadi, yang dianugerahkan ketika mengalami hidup baru di akhirat (Shihab 2006: 254-255).

\section{d. Metode penelitian berbasis nilai dan wacana tafsir}

Secara umum, wacana memiliki beberapa karakteristik, yaitu: pertama, tindakan; kedua, konteks; ketiga, historis; keempat, kekuasaan; dan kelima, ideologi (Eriyanto, 2001: 8-16). Karakteristik tindakan menghendaki naskah dipahami sebagai sebuah tindakan. Ia bukan berbicara untuk dirinya sendiri, tetapi untuk semuanya. Dengan kata lain, ayat al-Qur'an diturunkan sebagai sesuatu yang bertujuan. Bahasanya kemudian disusun sedemikian rupa dalam berbagai bentuk penyajian. Dalam hal ini, peneliti harus jeli melihat fungsi ayat yakni sebagai alat untuk memengaruhi, mendebat, membujuk, atau membantah. Karakteristik konteks harus dipahami bahwa naskah adalah perpaduan antara teks dan konteks. Karena itu, teks tidak begitu saja bisa dilepaskan dari konteks. Ini berdampak pada perlakuan naskah tersebut dalam situasi dan kondisi tertentu. Hal ini berhubungan dengan keadaan al-Qur'an yang diturunkan secara bertahap dari surat al-'Alaq (QS. [96]: 1-5) hingga surat al-Baqarah (QS. [2]: 281) tetapi disusun dengan diawali surat al-Fatihah. Tidak masuk akal bila dakwah Nabi Muhammad SAW diawali dari sejumlah perintah yang tidak disukai masyarakat pada saat itu, kecuali mereka sudah memiliki kepribadian dan keimanan yang kuat. Karakteristik historis menghendaki bahwa naskah harus dipahami sebagai sesuatu yang diproduksi dalam situasi historis tertentu, dan sebagai respons atas situasi dan kondisi saat itu. Dengan kata lain, penting untuk meneliti al-Qur'an dengan melibatkan apa yang terjadi pada saat itu. Cakupan historis lebih luas dari konteks. Karakteristik kekuasaan menghendaki bahwa naskah tidak dipandang sebagai sesuatu yang netral, wajar, dan bebas kepentingan, tetapi sebagai bentuk pertarungan kekuasaan. Dengan kata lain, penting untuk memahami bahwa 
turunnya al-Qur'an dengan segala maksud dan tujuannya adalah sarat dengan pertarungan-pertarungan kekuasaan. Bahkan beberapa ayat dengan secara terang-terangan menantang para penguasa yang ada untuk beradu dengan alQur'an. Kekuasaan dapat mengontrol dan mengendalikan keadaan. Karakteristik ideologi menghendaki bahwa naskah harus dipahami sebagai bentuk dari praktik ideologi tertentu. Sesuatu yang disampaikan akan lebih efektif ketika dianggap sebagai sebuah dogma kebenaran dan kewajaran. Ideologi penting dalam rangka mereproduksi, melegitimasi, mendominasi, mengontrol dan mengendalikan sesuatu.

\section{Contoh Kasus Penelitian Ayat-ayat Pendidikan Islam}

Surat al-'Alaq, [96]: 1-5 dapat dikategorikan sebagai ayat-ayat yang secara langsung berhubungan dengan bidang pendidikan. Kata pertama yang digunakan adalah kata iqra yang dalam terjemah berarti "bacalah". Kata ini diyakini sebagai kata yang pertama turun dari al-Qur'an, dengan catatan, bahwa basmalah bukan bagian dari ayat ini. Kata ini terambil dari kata kerja qara'a yang pada mulanya berarti "menghimpun". Dalam kamus, kata ini memiliki beragam arti di antaranya: menyampaikan, menelaah, membaca, mendalami, meneliti, dan mengetahui ciri-ciri sesuatu. Semuanya bermuara pada kata menghimpun (Shihab, 2007: 393). Dalam ayat tersebut, kata iqra berbentuk kata kerja yang membutuhkan objek. Akan tetapi dalam ayat di atas, objeknya tidak ditemukan, bahkan pada ayat berikutnya juga tidak ditemukan. Karena tidak memiliki objek, maka semua "hal" yang bisa dibaca adalah objek. Berarti, ayat di atas mengajak kepada manusia untuk selalu membaca apa pun yang bisa dibaca. Berdasarkan ayat di atas, awal turunnya wahyu adalah perintah untuk membaca, dan tidak membedakan jenis bacaan tertentu. Apapun yang dapat dibaca maka bacalah, yang penting dapat mendekatkan diri kepada Tuhan Pemelihara, sehingga dari hasil bacaan dapat lebih mendekatkan pembacanya kepada Tuhan.

Kata atau ayat di atas turun ketika Rasulullah SAW di Gua Hira. Sejumlah riwayat berbeda pendapat dalam menggambarkan peristiwa yang terjadi pada saat itu, terutama yang berkaitan dengan respons Rasulullah SAW ketika menerima wahyu. Dalam riwayat al-Thabari, Rasulullah SAW menjawab permintaan Jibril dengan perkataan mâ aqra'. Sedangkan dalam riwayat Ibn Katsir, Rasulullah SAW menjawab dengan perkataan mâ ana biqâri'. Jawaban pertama memberikan kesan bahwa Rasulullah SAW pandai membaca, dan pada saat itu beliau tidak mengetahui apa yang harus dibaca, sedangkan jawaban kedua, yang menggunakan struktur kalimat ismiyah, memberikan kesan dua: pertama, Rasulullah SAW bisa membaca tetapi tidak terbiasa membaca. Kedua, Rasulullah SAW tidak bisa membaca.

Kata berikutnya dari ayat di atas adalah rabbika. Kata ini disebut dalam alQur'an sebanyak 224 kali. Kata ini biasa diterjemahkan dengan Tuhanmu, tetapi yang lebih tepat adalah Tuhan Pemeliharamu. Dengan arti seperti ini, kata rabb 
bisa berarti Tuhan yang memiliki sifat mendidik, mengasuh, memelihara, dan mencipta (Daradjat, 1992: 26).

Kata rabb ini seakar dengan kata tarbiyah yang berarti pendidikan atau pemeliharaan, yaitu mengarahkan sesuatu setahap demi setahap menuju kesempurnaan kejadian dan fungsinya. Pengertian rabb atau rububiyyah ini mencakup pemberian rezeki, pengampunan dan kasih sayang, amarah, ancaman, siksaan, dan lain-lain kata yang senada dengannya. Diibaratkan dengan seorang anak yang diperlakukan sedemikian rupa oleh orang tuanya, yang tujuannya adalah mendidik dan memelihara (Shihab, 2006: 267).

\section{SIMPULAN}

Secara umum, landasan metodologis penelitian ayat-ayat al-Qur'an yang berhubungan dengan pendidikan mengacu pada prinsip dasar metodologi penelitian al-Qur'an. Prinsip dasar tersebut diuraikan ke dalam sejumlah metode analisis penelitian al-Qur'an, diantaranya; 1) metode analisis semantik; 2) metode analisis tematik; 3), metode analisis hermeneutik. Dari tiga metode analisis penelitian al-Qur'an tersebut dapat dikembangkan menjadi metodologi penelitian ayat-ayat al-Qur'an dalam pendidikan Islam, diantaranya; (a) metode penelitian ayat-ayat pendidikan Islam berbasis kata dan terjemah; (b) metode penelitian ayat-ayat pendidikan Islam berbasis asbâb an-nuұ̂ul; (c) metode penelitian ayat-ayat pendidikan Islam berbasis munâsabah dan (d) metode penelitian ayat-ayat pendidikan Islam berbasis nilai dan wacana.

Landasan teologi pendidikan Islam berangkat dari pemahaman bahwa alQur'an diturunkan kepada umat manusia sebagai petunjuk hudan li al-nâs. Dzat yang mengetahui secara pasti tentang maksud al-Qur'an yang sebenarnya adalah Allah SWT. Manusia dengan potensi akalnya mencoba menjelaskan maksud Allah SWT dalam kalam-Nya itu. Dasar pijakannya justru karena tujuan kehadiran Al-Qur'an sebagai budan/petunjuk itu. Sebagai petunjuk, bisa menunjukkan manakala petunjuk itu dapat dipahami. Pemahaman terhadap sesuatu yang harus dipahami itu tidak terlepas dari suatu penjelasan (tafsir). Dengan demikian, cukup beralasan ketika manusia pada dasarnya menebaknebak maksud Allah SWT karena secara teologis manusia itu tidak sempurna. Ketidaksempurnaan teologis itu dapat ditutupi ketika manusia melalui potensi akalnya menggunakan kaidah keilmuan yang dapat dipertanggunjawabkan. Hasil "tebakan" yang bersifat dzanni itu mengandaikan adanya upaya agar setiap "tebakan" itu selalu diupayakan lebih baik.

\section{DAFTAR PUSTAKA}

Al-Kholidi, Sholah. 1997. Membedah al-Qur'an versi al-Qur'an. Surabaya: Pustaka Progressif.

Al-Qaththan, Manna Khalil. 1973. Mabâhits fî̀ Ulûm al-Qur'ân. Riyadh: T.p. 
Al-Saowi, Ahmad et all. 1995. Mukjizat al-Qur'an dan Sunnah tentang Iptek. Jakarta: Gena Insani Press.

Al-Shabuny, Muhammad 'Ali. Al-Tibyân fî Ulûm al-Qur'ân.

Al-Suyuhti. Asrâr Tartîb al-Qur'ân.

Al-Zarkasyi. 1988. Al-Burhân fî Ulûm al-Qur'ân. Beirut: Dar al-Fikr.

Arkoun, Muhammad. 1996. Rethingking Islam. Yogyakarta: Pustaka Pelajar.

Baidan, Nashruddin. 2005. W awasan Baru Ilmu Tafsir. Yogyakarta: Pustaka Pelajar.

Burhanudin, Undang dan Hafiz Muslih. 2008. Ulum al-Qur'ân. Bandung: Insan Mandiri.

Daradjat, Zakiah. 1992. Ilmu Pendidikan Islam. Jakarta: Bumi Aksara.

Eriyanto. 2001. Analisis W acana: Pengantar Analisis Teks Media. Yogyakarta: LkiS.

Fakir, Muhammad. 2007. Qawâid al-Tafsir Laday al-Syîah wa al-Sunnah. Teheran:

Al-Majma' al-'Alamy li al-Taqrib baina al-Madzahib al-Islamiyah.

Hidayat, Komarudin. 1996. Memahami Bahasa Agama. Jakarta: Paramadina.

Irving, TB et all. 1984. Ajaran-ajaran Dasar Al-Qur'an. Bandung: Risalah.

Izutsu, Toshihiko. 1997. Relasi Tuhan dan Manusia: Pendekatan Semantik terhadap Al-Qur'an. Yogyakarta: Tiara Wacana.

Magestari, Noerhadi. 1998. Penelitian Agama Islam: Tinjauan Disiplin Ilmu Budaya. Bandung: Nuansa.

Nasuha, Khozin. 2009. Model-model Pengembangan Ulum al-Qur'an. ACIS.

Palmer, Richard E. 2005. Hermeneutika Teori Baru Mengenai Interpretasi. Yogyakarta: Pustaka Pelajar.

Rahman, Fazlur. 1983. Tema Pokok al-Qur'an. Bandung: Pustaka.

Rosadisastra, Andi. 2007. Metode Tafsir Ayat-ayat Sains dan Sosial. Jakarta: Amzah.

Shaleh, Subhhi. 1988. Mabâhits fî Ulûm al-Qur'ân. Beirut: Dar al-Ilm li al-Malayin.

Shihab, M. Quraish. 1993. Membumikan al-Qur'an. Bandung: Mizan.

Shihab, M. Quraish. 1998. Mukjizat al-Qur'an. Bandung: Mizan.

Shihab, M. Quraish. 2006. Perjalanan Menuju Keabadian. Jakarta: Lentera Hati.

Shihab, M. Quraish. 2007. Tafsir al-Mishbah. Vol 15. Jakarta: Lentera Hati.

Supena, Ilyas. 2008. "Epistemologi Tafsir, Ta'wil, dan Hermeneutika: Kajian Komparatif'. Jurnal Kajian Agama dan Filsafat, Vol. X, No. 1.

Suryadinata, M. 2007. "Isytiqâq Kabîr”. Jurnal Refleksi, Vol. IX, No. 2. 